alternate year and the date which is four weeks clear after the meeting of the Council at which its nominations are made. Nominations other than those made by the Council shall be lodged with the Registrar and accompanied by the written consent of the candidate to serve if elected. Should there be more nominations than vacancies, an election shall be held by ballot of the Members of the College. The ballot paper shall not indicate the method of nomination or the names of those nominating. If the number of nominees does not exceed the number of vacancies, these nominees shall be declared elected at the first meeting, whether of the Council or the Executive and Finance Committee, after the expiry of the period of four clear weeks in this paragraph referred to.

\section{Honorary Officers}

Fellows and Members of the College are reminded of their rights in connection with the forthcoming elections for the offices of Dean. Registrar, Treasurer, Editor and Librarian. All Honorary Officers are eligible for re-election, although the Treasurer, Professor Kolvin, does not wish to stand for re-election.

The nominating meeting of Council will be held on 29 April 1999 and the last date for receiving nominations will therefore be 27 May 1999. The relevant Bye-Laws and Regulations are printed below.

\section{Extracts from Bye-Laws and Regulations} Bye-Law XII THE HONORARY OFFICERS

1. The Council shall in accordance with the Regulations, make its nominations for the offices of Dean, Registrar, Treasurer, Editor, Librarian at the first meeting after the name of the President for the next ensuing College year has become known. Written nominations for the above Honorary
Offices, accompanied in each case by the nominee's written consent to stand for election, may also be lodged with the Registrar at such time as may be prescribed by the Regulations provided that each such nomination is supported in writing by not less than twelve Members of the College who are not members of the Council.

2. The Dean, Registrar, Treasurer, Editor and Librarian shall be elected from among the Fellows by the Members of the College, in each case in accordance with the procedure prescribed by the Regulations.

\section{Regulation XII ELECTION OF THE OTHER HONORARY} OFFICERS

1. The method of electing the Honorary Officers other than the President and the Vice-Presidents and Sub-Deans shall be the same as that for electing the President, * save that nominations from Members of the College who are not members of the Council shall be lodged with the Registrar between the first day of January in any calendar year and the date which is four clear weeks after the meeting of the Council which is first held after the name of the President for the next ensuing College year has become known, or (as the case may be) which is four clear weeks after that meeting of the Council which, in the case of a tie on the second ballot. determines the election of the President.

*i.e. Written nominations accompanied in each case by the nominee's written consent to stand for election, may be lodged with the Registrar. provided that each such nomination is supported in writing by not less than twelve Members of the College who are not members of the Council. An election by ballot shall be held in accordance with the provisions of the Regulations.

\title{
Honorary Fellowships
}

\author{
Anne Dean
}

Nominations to the College's Honorary Fellowship will be discussed at the June meeting of the Court of Electors.

The regulations of the College state under ByeLaw Section VI that:
"Subject to the Regulations the College may elect as an Honorary Fellow any person, whether or not he is a member of the medical profession, who either is eminent in psychiatry or in allied or connected sciences or disciplines or has rendered distinguished 


\title{
THE COLLEGE
}

service to humanity in relation to the study, prevention or treatment of mental illness or to subjects allied thereto or connected herewith or has rendered notable service to the College or to the Association."

Nomination forms are available from Ms Beverley Fiddimore, Department of Postgraduate Educational Services, to whom nominations for the Honorary Fellowship should be sent by 1
April 1999. Such nominations must contain recommendations by no less than six Members of the College, and include full supporting documentation.

ANNe Dean, Head of Postgraduate Educational Services, Royal College of Psychiatrists, 17 Belgrave Square, London SWIX 8PG

\section{Photographs of College Fellows and Members}

\author{
Margaret Harcourt Williams
}

The College holds a number of photographs of Fellows and Members. It is proposed that, if a Fellow or Member has supplied the College with a photograph in the past. the supplying of such a photograph is deemed to have licenced the College in the use of this photograph, unless a Fellow or Member informs the Head of Post- graduate Education or the Archivist that they object to this.

MARGARET HARCOURT WILlIAMS, College Archivist, Royal College of Psychiatrists, 17 Belgrave Square, London SW1X 8PG

\section{The College archives}

\section{Records of Special Commiftees, Divisions and Sections}

\author{
Margaret Harcourt Williams
}

The College archives are the part of the paperwork created by the College and its predecessor bodies that has been considered worthy of permanent preservation for administrative or historical reasons. The core of this archive is the surviving minutes of the Council and standing committees that are preserved either in printed form in the Journal of Mental Science (JMS), now The British Journal of Psychiatry (BJP) or in manuscript form. These were 